\title{
Optimization Of High Quality Social Media Backlinks To Improve Search Engine Optimization (SEO) On UMKM E-Commerce Website
}

\author{
Wiwit Agus Triyanto ${ }^{1}$, Nanik Susanti ${ }^{2}$ \\ \{at.wiwit@umk.ac.id ${ }^{1}$, nanik.susanti@umk.ac.id ${ }^{2}$ \} \\ Study Program of Information System, Engineering Faculty, Universitas Muria Kudus, Kudus, \\ Gondangmanis Kudus Central Java - Indonesia, 59327 ${ }^{12}$
}

\begin{abstract}
UMKM is an important sector which has a big role for economic in Indonesia. The most frequent problem is still lack of UMKM who have sufficient human resources for development of business. This research based on palnning of research, collect data, analyze the needs of system, sytem design, implementation system, and testing system. Backlinks optimization, especially backlinks of high quality social media in according with website e-commerce UMKM can improve score SEO significantly and can put in the top position so that can improve the traffic and can resulting to increase the sales. The sale of increased can also provide an opportunity to work all people arround UMKM, so it can improve people welfare. As for constraints in optimization in this tag html is need optimization other SEO ongoing base, so the SEO score will not go down and result in the decrease of visitor traffic to the website.
\end{abstract}

Keyword: SEO, e-commerce, UMKM, social media, backlinks.

\section{Introduction}

UMKM is the most important which have big impact for economic in Indonesia. This sector have potential development and compete in MEA globalization market, it cause that UMKM more confidence and resistence to economic cricis if UMKM is an important sector which has a big role In the Indonesia Economic system. UMKM has development and compete potential In the world market (MEA). The reason are they can more endure and resistance to Economic crisis than a big company.

In 2015, according to Badan Pusat Statistik (BPS), amount of UMKM in Indonesia reach 3.385.851 of micro industry and 283.022 Of small industry [1]. The most frequent UMKM is still lack Of human resources for business development. Most UMKM still rely on tradisional selling system. Only a few that use technology infomation especially websites for promoting. There must be an online based sales system (E-Commerce) that can facilitate the promoting process and sales process Of the UMKM product easier. Promoting the UMKM product by Ecommerce can increase the sales rate because the product can be acsessed by all over the world. so, by increasing it, the welfare Of UMKM can also be improved.

Despite of, there are a few people still do not know how to get the visitors on the UMKM websitenya, who Will be the buyers of the UMKM products. To increase the number Of visitors, there must be a special strategi which are effective and easy. A fairly effective strategi is by using search engine optimization (SEO) technique. The aim Of using SEO is the website

ICCSET 2018, October 25-26, Kudus, Indonesia

Copyright (C) 2018 EAI

DOI 10.4108/eai.24-10-2018.2280633 
page can appear In the first page Of the search engine (Google,yahoo,bing). Therefore, consumer or buyer can find the website easily.search engine will analize the website quality by looking the number Of link that pointed to the website. A link can metaphor as refferal sources and the more the website that pointed to the refferal resources the more trustable the website on the search engine. However, now not all the backlink can be avowed by search engine. Only backlink from high quality website which counted and one Of it from social media.

By using high quality social media backlink optimization for increasing SEO on the Ecommerce website then UMKM can develop its marketing and result in increased sales. Increased sales can also provide work opportunities for peoples around UMKM and improve people's welfare.

\section{Literature Review}

\subsection{Theory / Concepts}

Search Engine Optimization, commonly abbreviated as SEO is a series of systematic processes aimed at increasing the volume and quality of traffic through search engines to certain websites by utilizing the working mechanism or search engine algorithms. The goal of SEO is to place a website at the top position, or at least the first page of search results based on certain targeted keywords. Logically, websites that occupy the top position in search results have a greater chance of getting visitors [2].

Backlink is a link that usually shaped images or text from a particular website. If the link is clicked, then the page will directly lead to the website so that the link becomes a backlink to the website. Social Media Backlinks is a backlink that comes from social media and leads to a website in the form of text and images [3].

Electronic Commerce (E-Commerce) is defined as the process of purchasing and selling of products, services and information made electronically by utilizing computer networks [4].

UMKM in English term is Micro, Small and Medium Enterprises. UMKM are regulated under Law No. 20 of 2008 on Micro Small and Medium Enterprises [5].

\subsection{Previous research}

Himawan, Arisantoso and Asep Saefullah Made a research the titled is "Analysis of the Effects of the Use of Search Engine Optimization (SEO) on E-Commerce Websites" which states that E-Commerce is one of business transaction of goods and services conducted electronically using internet. There are many ways that can be used to increase the number of visits on a website page, especially online stores. Some popular ways to use is to use blogs, search engine optimization, advertise through google adsense or facebook fan page, the use of social media networking is indeed climbing trend in recent years [6].

Another research is in the journal by Ayush Jain and Meenu Dave entitled "The Role of Backlinks in Search Engine Ranking", in their research explaining that Search Engines are designed to efficiently crawl and index web pages for better search results. There is a large contribution of link building to the popularity of a website. The number of backlinks plays an important role for the webiste ranking on the machine. Backlinks are links received by a website from another website. For a good SEO ranking, it is very important for a link to be 
linked to a website that also has a high ranking. The backlinks created must be relevant to the niche website. If the backlink on a keyword increases then the ranking of keywords on search engines will also increase [7].

Research journal by Andi Rofik Lutfi Hidayat and Ali Tarmuji with the title, Application Analysis of SEO (Search Engine Optimization) and SMO (Social Media Optimization) on Faculty Websites at Ahmad Dahlan University to Increase Search Engine Ranking, from their research explain that A website has performance with search engine. If the performance get better, it will make the website get visitors. Therefore, it is necessary to optimize SEO (Search Engine Optimization) and SMO (Social Media Optimization). The problems seen from the less optimal of SEO parameters and the popularity of websites through social media is still lacking, so it needs to be optimized. Analysis of faculty website at UAD aims to improve the website is positioned as the first page or the first page of search engines and increase the popularity of websites in social media [8].

\section{Method}

The stages Of the studies are:

\subsection{Research Planning}

At this stage a research plan will be conducted at Muria Kudus University

\subsection{Collecting data}

To obtain accurate data then in this study the data collection is collected by:

1) Observation

At this stage collecting data through observation and recording of problems encountered, promotion and sales of products UMKM.

2) Literature review

At this stage looking for a theory that can be used as a base of theory / framework in research such as e-commerce theory, research journals that discuss about ecommerce, research journals that discuss about industry, research journals that discuss About develope the system. Looking for the suitable technology. A research journal that discusses the development of systems, to find the appropriate methodologies and to compare existing theories facts in reality field.

\subsection{System Requirement Analysis}

At this stage, analysis of needed in High Quality Social Media Backlinks optimizations is Made to Improve Search Engine Optimization (SEO) On E-Commerce Website of UMKM, the activities are:

1) Analysis and identification of information system needs of UMKM e-commerce. Activities are problem analysis, requirements analysis and generating system analysis. 
2) Design of e-commerce Information UMKM System Model. The activities are conceptual design, detail design and database.

\subsection{System Design}

At this stage interface design e-commerce website UMKM is arranged.

\subsection{System implementation}

At this stage, The e-commerce website UMKM is done by using Meta tag HTML optimization. Website is made to do promotion some product and transaction product promotion with online to Volya Bag Collection. E-commerce website which use backlinks in social media can speed up the index and SEO score in website. So, this traffic of website can improve more fast. Website which have high traffic can improve high transaction seller than as social media to advance UMKM and introduce UMKM in the world. The long term impact can happen if seller increase, UMKM should improve production. The seller which increase can give job opportunity to people arround UMKM, so it can increase the welfare of people.

\subsection{Testing of The System}

In this section, testing and measurement of SEO in UMKM e-commerce website. Through https://sesitecheckup.com and https://www.seocentro.com/

\section{Result and Discussion}

\subsection{Identification Hardware Needs}

Identification hardware needs use are as follow:

1) Personal Computer / laptop

2) Processor Core i5

3) RAM DDR3 (4GB)

4) HDD $1 \mathrm{~TB}$

5) Keyboard

6) Maouse

7) Modem

\subsection{Identification Software Needs}

Identification Software Needs use are as follow:

1) Web browser (mozila firefox, google chrome, opera, etc )

2) Website E-commerce UMKM 


\subsection{Identification Brainware Needs}

In order for the implementation to run smoothly, it takes a user who is able to run or operate the computer and run the website e-commerce https://www.valyabags.store that has been made.

\subsection{Testing}

The optimazation of high quality social media backlinks on e-commerce website is done by optimizing backlinks obtained from social media, so SEO score can increase. There is Meta Tag to optimazation backlinks of social media.

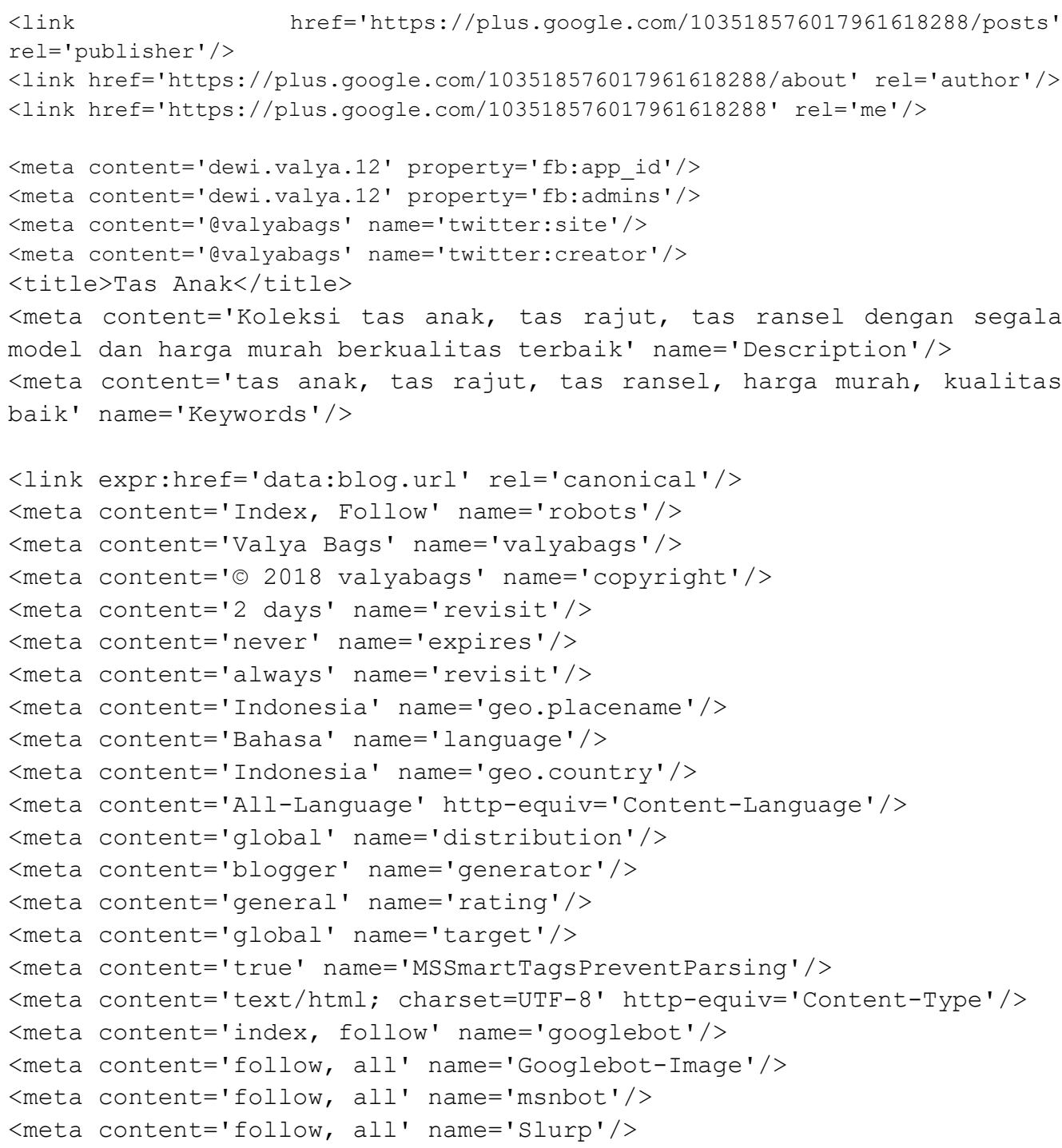




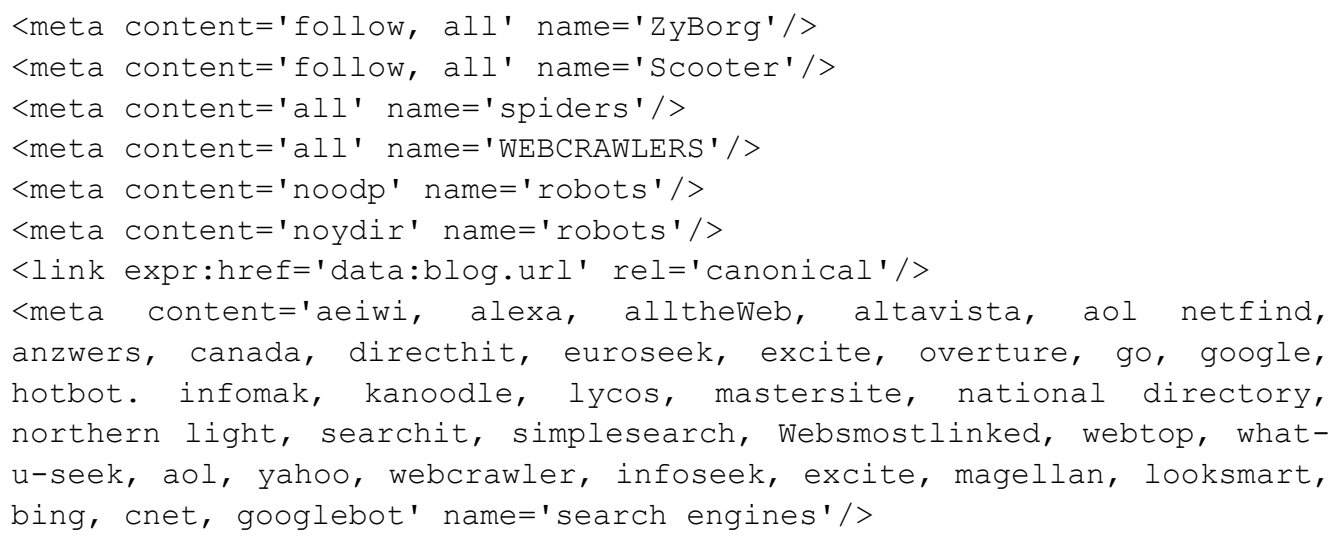

Research of SEO done online through 2 sites SEO, there is https://seositescheckup.com and https://www.seocentro.com/ there is the results of testing SEO score :

Table 1. Score Measurement SEO.

\begin{tabular}{cccc}
\hline Check Site SEO Score & $\begin{array}{c}\text { SEO Score Without } \\
\text { Optimization }\end{array}$ & $\begin{array}{c}\text { SEO Score with } \\
\text { Optimization } \\
\text { Social Media } \\
\text { Backlinks }\end{array}$ & $\begin{array}{c}\text { Presentation } \\
\text { Raise }\end{array}$ \\
\hline https://seositecheckup.com & 63 & 70 & $11 \%$ \\
https://www.seocentro.com & 61 & 65 & $7 \%$ \\
\hline
\end{tabular}

From table above can see score rise when looking for optimazation keyword meta and description meta in website www.valyabags.store. The initial view of valyabags.store have many section, there are Home, About, Contact Us. In the above section have slide show products of choice, in other can also show the categorize best seller, limited edition, discounts, in trends. The initial view can be seen in figure 1 .

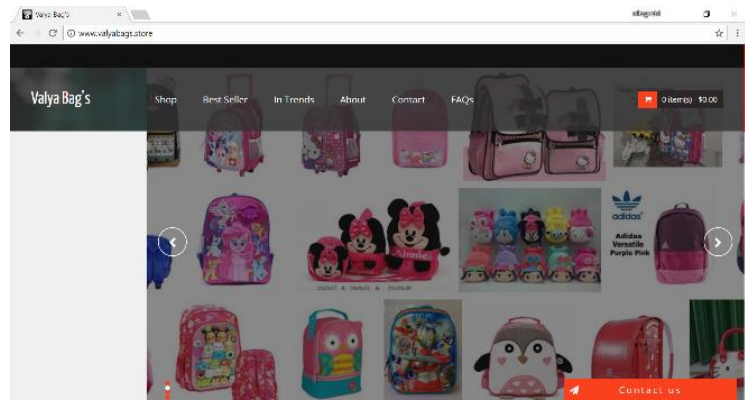

Fig. 1. fisrt show.

The display featuring bags manufacturated by valya bag. Product display can be seen in figure 2 . 


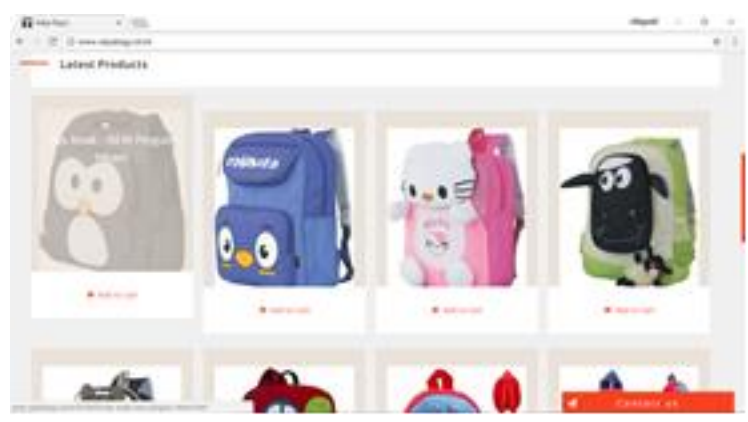

Fig. 2. Product Display.

Detail display product information bag, such as description, proce and color choice. The product detail view can be seen in figure 3 .

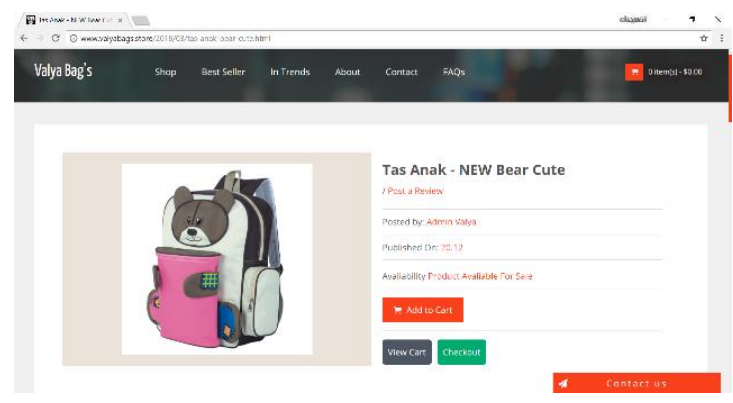

Fig. 3. Detail Display Product.

\section{Conclusion And Suggestion}

The backlinks optimization, especially social media backlinks which as UMKM ecommerce website can increase SEO score, so it can place a web site in the high position, so visitors in the web traffic is improve and give impact the increase of seller. The seller can also increase and can give people arround UMKM to improve the welfire of people.

The optimization of meta tag html in this e-commerce website successfully excuted well and ready to be used, as neeed to do is the manager of UMKM e-commerce website have to diligently update this product, so that visitors more interested to do transaction.

The obstacles in thisoptimization of meta tag html is need for other SEO optamization ongoing basis, so that SEO score will not go down and the result in decreased traffic of visitors to the website.

\section{References}

[1] B. P. Statistik, "Tabel Perkembangan UMKM," 2015. [Online]. Available: http://bps.go.id/.

[2] F. Amin, "Rekayasa Website Teater Institut Seni Indonesia (ISI) Yogyakarta dengan Content Management System (CMS)," Din. Inform., vol. 6, 2014. 
[3] K. Geetha, S. and Sathiyakumari, "Backlink Analysis using Mozrank Algorithm of Blogs," Int. J. Comput. Sci. Appl., vol. 1, 2012.

[4] M. Syah, R., Iqbal, M. and ELveny, "Pembangunan Aplikasi E-Commerce dalam Menunjang Penjualan Produk Pada CV.Riztech," TECHSI, vol. 4, 2014.

[5] A. Anggraeni, F, D., Hardjanto, I., and Haya, "Pengembangan Usaha Mikro, Kecil, Dan Menengah (UMKM) Melalui Fasilitasi Pihak Eksternal dan Potensi Internal (Studi Kasus pada Kelompok Usaha 'Emping Jagung' di Kelurahan Pandanwangi Kecamatan Blimbing, Kota Malang),' J. Adm. Publik (JAP), vol. 1, pp. 1286-1295, 2013.

[6] E. Himawan, "Analisa Pengaruh Penggunaan Search Engine Optimization (SEO) pada Website ECommerce," in Prosiding SESINDO, 2015.

[7] M. Jain, A. and Dave, "The Role of Backlinks in Search Engine Ranking., International Journal of Advanced Research in Computer Science and Software Engineering," vol. 3, 2013.

[8] A. Hidayat, A.R.L. and Tarmuji, "Analisis Penerapan SEO (Search Engine Optimization) Dan SMO (Social Media Optimization) Pada Website Fakultas Di Universitas Ahmad Dahlan Untuk Meningkatkan Peringkat Di Search Engine," J. Sarj. Tek. Inform., vol. 2, 2014. 